\title{
Analysis of Language Learning Strategies Used by Two Groups of Students of Differing Age Range ${ }^{1}$
}

\section{Análisis del uso de estrategias de aprendizaje del lenguaje usadas por dos grupos de estudiantes con diferente rango de edad}

\author{
Francisco Javier Suesca Torres ${ }^{2}$ \\ Institución Educativa Departamental Agustín Parra \\ franciscojaviersuesca@hotmail.com \\ Andrés Mauricio Torres Pérez ${ }^{3}$ \\ Institución Educativa Técnica La Laja \\ andresmtp@hotmail.com
}

Received: March 3, 2016

Accepted: June 9, 2016

How to cite this article (APA, $6^{\text {th }}$ ed.): Suesca, F., \& Torres, A. (2016). Analysis of Language Learning Strategies Used by Two Groups of Students of Differing Age Range. Enletawa Journal, 9 (2), 55-72.

\begin{abstract}
This short exploratory study aims to analyze the language learning strategies used by part of two groups of students with different age range in seventh and eleventh grade. The instruments used to carry out this study were: an adapted

1 This research report emerged from the researchers' interest in making further inquiries into Language Learning Strategies based on a series of works that took place in a seminar called Teachers Training at the UPTC.

2 Holds a B.A. in Modern Languages: Spanish-English from Universidad Pedagógica y Tecnológica de Colombia. He is currently working as a full time teacher at Institución Educativa Agustín Parra in Simijaca. His research interests are related to socio-political view of language such as linguistic imperialism, policies of standardization and teachers EFL beliefs.

3 Holds a B.A in Foreign Language Teaching: English-French from Universidad de Pamplona. He works at a public school called Institución Educativa Técnica La Laja de Moniquirá. His research interests encompass rural education, socio critical research, critical pedagogy, and ESL.
\end{abstract}


questionnaire to identify Language Learning Strategies (LLS), a focus group discussion, and an interview. The results show that age is an important factor when determining LLS. However, it was also found that there are other variables such as task nature, course methodology, and parents' availability, among others, that may influence strategy choice.

Key words: Language learning strategies, Strategy Inventory for Language Learning (SILL), Age difference.

\section{Resumen}

Este estudio exploratorio corto busca analizar las estrategias de aprendizaje del lenguaje usadas por dos grupos de estudiantes con diferente rango de edad en los grados séptimo y undécimo. Los instrumentos usados para llevar a cabo este estudio fueron: la adaptación de un cuestionario para identificar las estrategias de aprendizaje del lenguaje (EAL); una discusión de grupo focal y una entrevista. Los resultados muestran que la edad es un factor importante cuando se determinan las EAL. Sin embargo, se encontró que hay otras variables tales como la naturaleza de las tareas, la metodología del curso y la disposición de los padres, entre otros, que podría influenciar la elección de la estrategia.

Palabras clave: Estrategias de aprendizaje del lenguaje, SILL, Diferencia de edad. 


\section{Introduction}

This short exploratory study aims to analyze the language learning strategies used by two groups of students with different age ranges, namely in seventh and eleventh grade. Studies done by Fillmore (1979), Ellis (1989), Oxford (1989), O'Malley and Chamot (1990), and Fewell (2010), on language learning strategies have been of great significance since they provide key facts for understanding students' learning processes which may lead to a "successful" or "proficient" use of a foreign language (L2). In order to facilitate the acquisition, internalization and use of an L2, it is important to be aware of the array of modes through which students learn. In this sense, Oxford (1990) points out that "learners need to learn how to learn, and teachers need to learn how to facilitate the process." (p. 201).

At present, in some schools around the world, children and teachers have the opportunity to identify learning styles, self-monitoring, selfdirected learning, learner autonomy and language learning strategies, as outlined in studies made by Chamot (2005), Lee (2014), and Chen (2014). These different types of opportunities allow students to understand and know themselves in connection with their potential for raising awareness on their own strategies to understand knowledge.
Thus, taking into account the aforementioned facts, this study aims to analyze the language learning strategies used by two groups of students (ten students aged 12-13 and ten students aged $16-17$, in $7^{\text {th }}$ and $11^{\text {th }}$ grade respectively) at two public schools in Colombia in order to reveal how and to what degree age governs the use of LLS.

\section{Literature Review}

\section{Learning Strategies.}

In the cognitive field, the term 'strategies' was first coined by Bruner, Goodnow and Austin (1956) to refer to regularities in decision-making. However, researchers such as Brown (1982), Derry and Murphy (1986), Wade, Trathen and Schraw, (1990), Weinstein and Mayer (1986), Rubin (1975), O'Malley and Chamot (1990), Stern (1975) and Oxford (1990) have provided different definitions and classifications of strategies in the field of language learning. For instance, Oxford (1990) describes learning strategies as the specific behaviors or thought processes that students use to enhance their own L2 learning. Additionally, Oxford goes beyond by stating that "the objective of using LLSs is to make learning easier, faster, more enjoyable, self-directed, effective, and even transferrable to new situations". Also, Oxford states that learners are influenced by factors such as gender, age, social status, etc. 
Similarly, Chamot (2004) states that learning strategies are the thoughts and actions that individuals use to accomplish a learning goal. Other authors such as Tarone (1981, p. 290) include other terms when defining learning strategies, stating that they are "an attempt to develop linguistic and sociolinguistic competence in the target language to incorporate these into one's inter-language competence."

In addition, it is relevant to highlight that the taxonomies proposed by Rubin, O'Malley, Stern and Oxford, among others, are the most common ones (Chamot, 2004), with Oxford's classification being widely used as it is considered a complete instrument in terms of validity and reliability since her taxonomy has been used in different settings with variables such as language and culture (Gavriilidou \& Mitits, 2016). Additionally, it has been used as a referent for the designing of adaptations of other inventories. According to Droździał-Szelest (1997) initially, Oxford classified LLS into two main categories based on Rubin's division of strategies: direct and indirect strategies. As stated in Griffiths and Oxford (2014), Oxford included memory, cognitive, and compensation strategies in the direct category, while the indirect category included metacognitive, affective and social strategies. Recently, she refined her classification into four categories: cognitive, affective, socio-cultural interactive and meta-strategies.

\section{Strategy Inventory for Language Learning (SILL).}

Several studies made by Chamot (2005), Pineda (2010) and Lee (2014) on language learning are based on the Strategy Inventory for Language Learning (SILL) which was created by Oxford in 1990. The main purpose of the inventory was to assess the frequency of use of various language learning strategies. There are two versions of the SILL: Version 5.1 is used for foreign language learners, whose native language is English, whereas version 7.0 is used for learners of English as a foreign/second language (Gavriilidou \& Mitits, 2016; Russell, 2010).

\section{Adaptation of the SILL.}

Different researchers have made adaptations to the SILL to fit their respondents' contexts and have included variables such as age, language, gender, etc. (Ardasheva \& Tretter, 2013; Gavriilidou \& Mitits, 2016; Lavasani \& Faryadres, 2011; Lee, 2014). For instance, Lee (2014) took into account different SILLs to design a new version which considered factors such as age and school context. In her study, she found that the new instrument was useful because it was shorter, simpler, and it covered the main categories found in the literature about LLS.

In relation to our current research, it was found that few studies have been applied to school children and 
adolescents (Platsidou \& Sipitanou, 2015). It is also important to mention that the only available recognized instrument for younger students is very expensive, complex and difficult to use (Lee, 2014; Stroud, 2006). As a result, less importance has been given to this population in contrast with college students (Stroud, 2006).

Thus, it becomes necessary to discover alternative ways of allowing teachers to adopt methodologies that demonstrate an understanding of the primacy of empirically examining their students' patterns of LLS use along with the possible implications for teaching methodology, curriculum design, and strategy training, especially given the particular conditions of our contexts (lack of resources and EFL research in the field of LLS).

\section{Methodology}

\section{Setting.}

The present study was carried out in two different schools: One school is located in Cundinamarca and the other in Boyacá. Both schools have the particularity that students come mainly from rural areas. However, the former setting is located in an urban context while the latter school has a limited access to the town and many students have to walk long distances to get to school.

The participants in Cundinamarca were seventh graders, aged between 12 and 13 years old; the participants in
Boyacá were aged between 16 and 17 years old. As for parents' involvement in students' activities, they seem to be largely unconcerned with the educational process. The main sources of income for the families in both groups are agricultural activities and animal husbandry. The quantity of parents that hold a professional degree is negligible.

\section{Data Collection Instruments}

\section{Questionnaire.}

Questionnaires are widely used since they provide researchers with information such as the distribution of characteristics, attitudes or beliefs. (Marshall \& Rossman, 1995; Wilson \& McLean, 1994). Moreover, as mentioned in the literature review, the SILL can be adapted for specific purposes. In this case, we adapted Lee's SILL (2014) because it condensed information from a broad range of strategies into four main categories: cognitive, metacognitive, resource management, and motivationaffective. $^{4}$

The adapted instrument was called the Local Language Learning Strategy Inventory $^{5}$ (LLLSI), and it was tailored to meet the particular needs of the study, especially in terms of feasibility and ease of use for local teachers. It included

4 The reader will find in the Appendix 1, a sample of the adapted questionnaire.

5 The LLLSI was translated into Spanish to make sure that all respondents understood the categories and the items. 
the above-mentioned categories, a oneto-five Likert (1932) scale that provided a range of responses to a given question or statement, as well as an adaptation of the category names for students' readability and understanding. The LLLSI was administered to 10 students in each group.

These aforementioned categories were renamed as follows:

1. Cognitive $=$ Perceptions.

2. Metacognitive $=$ How do I manage my own perceptions?

3. Resource-management $=\mathbf{M y}$ planning.

4. Motivation-affective domains $=$ What makes me feel motivated?

\section{Focus group.}

A focus group is a contrived setting used to discuss particular topics where the interaction of groups provides data and outcomes which will likely be helpful for subsequent interviews and/ or questionnaires (Krueger, Morgan, Bailey and Robson as cited by Cohen, Manion \& Marrison, 2007). Hence, we decided to conduct a focus group to take advantage of the opportunity to address certain themes among the participants and glean insights from such interactions (Krueger; Morgan; Stewart \& Shamdasani as cited in Creswell, 2007).

Before conducting the focus group, the location, time and the date were set up and communicated to the participants. The focus group was conducted at the two different schools and was comprised of three parts: the first part was the introduction, during which the purpose of the research and general information about issues concerning confidentiality, ethics and procedure were explained; the second part explored of the use of learning strategies; and the third part consisted of closing the focus group and thanking the participants.

In order to record input data, a mobile built-in audio-recording application especially for interviews was used. This application includes a speech to text option which can be very helpful for transcribing individual contributions. The discussion was carried out with 10 students from each grade respectively.

\section{Interview.}

Burgess (as cited in Richards, 2009, p. 102) describes a typical interview as a 'conversation with a purpose' and Kvale (as cited in Richards, 2009, p.5) describes it as a 'professional conversation'. In this case, the purpose of this procedure was to gain a better understanding about LLS development based on what students had revealed in the previous two instruments described above. In addition, we decided to use the interview because it is a tool that permits us to collect more detailed data than questionnaires alone; moreover, as Lankshear and Knobel (2004) point out, "interviews remain the best available means for accessing study participants' 
opinions, beliefs, values and situated accounts of events at a particular point in time" (p.199).

A semi-structured interview was conducted employing a one-on-one interview format with open-ended questions. This interview was comprised of 10 questions about LLS use and other variables that students had mentioned in the focus group. The interviews were subsequently analyzed in order to compare and contrast the data provided by the two groups.

\section{Procedure}

The administration of the LLLI questionnaire provided us with quantitative data which measured the LLS that students used. The focus group discussion about learning strategies with the initial participants enabled us to have a better understanding of how students made sense of the use of LLS. The semi-structured interview was designed to elicit information about specific characteristics from students regarding LLS use.

Upon thorough review of different published research findings regarding LLS development, it appeared evident that most of them present discussions drawn largely from quantitative data (e.g. Chang, Liu \& Lee, 2007; Chen, 2014; Chen \& Jonas, 2009; Lee, 2014; Platsidou \& Sipitanou, 2015). Traditional methods of data collection and analysis often focus on single input modes, thus it was decided to draw on a triangulation method aimed at using different data sources to identify convergence and divergence points, taking into account the counsel of Lankshear and Knobel (2004). Because this was a qualitative study, we felt it important to give participants a voice as they experience the same event differently; in doing so, participants draw different conclusions and offer varying explanations and perceptions (Hood, 2009).

In order to organize the data for the analysis, we decided to use a method of organization broken down by instrument type (Cohen, Manion \& Marrison, 2007) which was then analyzed by issue and by group (seventh graders and eleventh graders). For ease of analysis within this data organization approach, a particular color was assigned to each LLS category and a number to each one of the participants in order to readily find patterns among the three instruments used.

\section{Results and Discussion}

In the figure below, the reader will find the results from the questionnaire which indicate that students in seventh and eleventh grades generally showed a higher use of cognitive and motivation-affective strategies in contrast to resource management and metacognitive strategies. 
Figure 1. Language Learning Strategies Use.

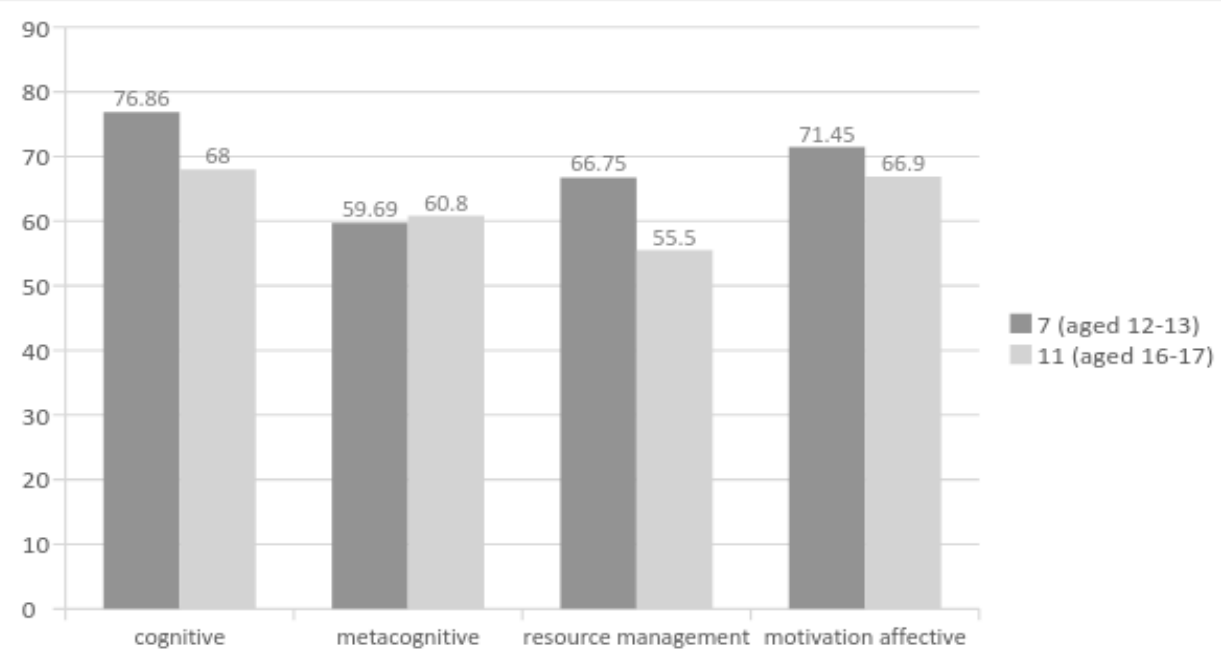

\section{Strategy choice and course level.}

Upon completing the data analysis, it was concluded that language learning strategy use is influenced by two main factors, namely the teacher's methodology and nature of the task. Students in both groups reported that the use of repetition as a way to memorize was characteristic of different teachers' methodologies:

"Pues antes en primaria lo ponían a uno a dibujar personas o algo en inglés y ahora pues le toca a uno, le ponen textos o algo $y$ tiene que aprendérselos".

[Excerpt from focus group discussion, student \#1, seventh grade]

This could mean that students' strategy use is closely related to the time of exposure to a determined instructional method used by teachers in previous years. This echoes conclusions by Sutter (as cited in Oxford, 1989) which indicate that students tend to prefer language learning strategies modeled by a program's general method of instruction and that this preference is more noticeable the longer they are exposed to said methodology. Eleventh graders, for example, report a high use of repetition techniques during their daily activities, as reflected in the following excerpt:

\footnotetext{
"Bueno para memorizar la estrategia que más utilizo es repetir y hacer dibujos. Las (estrategias de repetición) que yo utilizo, no sé, de pronto escribir varias veces para que a uno se le quede la palabra o repetirla o escuchar, no sé, cosas alusivas" [Excerpt from interview, student \#11, eleventh grade]
} 
As for the nature of the task, it seems that the characteristics of activities established for a particular course influences the use of LLS in students. It was evidenced throughout the data analysis that students perceive an increase in task complexity as they progress over the years. Additionally, the use of different activities based on the subject matter at hand leads them to use specific strategies for specific purposes. For example, students report the use of imagery-based stra-tegies in biology, social studies, and mathematics, while repetition is preferred in English activities. The following response describes the above-mentioned argument:

"En español de pronto mapas conceptuales, cuadros mentales que no se practican en Inglés"

[Excerpt from interview, student \#14, eleventh grade]

\section{Learning style and strategy choice.}

Some students reported the use of a preferred language learning style, independent of the nature of the task or the teacher's methodology. It was observed that although most of the learners appear strategically unaware and do not demonstrate an articulated use of particular metacognitive processes, they do have a perception of some learning styles such as sensory modality preferences (Oxford, 2003) which they then relate to specific strategies (e.g., using drawings as a way to memorize).
The following excerpt illustrates how one student uses a preferred technique when he is asked to learn vocabulary:

“...Cuando es como algo para entender y para no andar repitiendo a veces hago los dibujos y entiendo que digamos si toca escribir sobre una casa y en vez de aprenderme la casa hago el dibujo"

[Excerpt from interview, student \#10, seventh grade]

Accordingly, Wong (2011) argues that learning styles and corresponding strategies are often employed regardless of the methodology or skill being mastered, which seems to be the case with the seventh graders, many of whom make use of imagery independently of the requirements of the task. On the other hand, eleventh graders seem to use a wider range of techniques, but as opposed to younger learners, they do not frequently report the use of imagery, which may be related to the kind of activities younger learners preferred in their early stages:

Student \# 14: “...Pues no tanto porque los dibujos los hacía uno cuando estaba hasta ahora aprendiendo".

Interviewer: "Y ahora qué actividades prefiere hacer?"

Student \# 14: "pues a veces escucho audios y repito palabras y cosas por el estilo".

[Excerpt from interview, student \#14, eleventh grade] 


\section{Consciousness of language learning strategy use.}

Throughout the questionnaire, focus group discussions, and the interviews, it was observed that the use of metacognitive strategies is one of the weakest strategic elements in terms of applying metacognitive strategies to enhance awareness of self and/or awareness of peers. As mentioned above, few students demonstrated a monitored use of their LLS. Nevertheless, eleventh graders communicated a better understanding of the processes involved in the use of strategies for learning throughout the focus group discussions and the interviews. Conversely, seventh graders initially appeared to be unaware of their metacognitive strategies and did not have an apparent systematic view of how they learn. However, it was evidenced in the focus group that when prompted via direct explanation or drawn from the contributions of other participants who talked about their strategies, students who were not initially aware of their strategy use began to make more concrete contributions in terms of articulating ways in which they perceive they learn best:

“...Cuando es como algo para entender y para no andar repitiendo a veces hago los dibujos y entiendo que digamos si toca escribir sobre una casa y en vez de aprenderme la casa hago el dibujo"

[Excerpt from interview, student \#10, seventh grade]
With reference to this fact, it is important to mention that consciousness awareness and monitoring of strategies is a complex process, especially since a strategy might become seemingly automatic yet then fade from awareness (Lee \& Oxford, 2008). However, strategies can be brought back into consciousness as was indicated in the focus group discussions and interviews with some students.

\section{Time disposal and strategy choice.}

Three main factors were identified as influential regarding social relations in their environment. LLS use seems to be influenced by school requirements, parental involvement, and leisure activities.

Both groups reported awareness of the influence of age in the managing of their time. Students claimed that as they grow up, they acquire more responsibilities in school and that age is a variable that influences autonomy. For example, eleventh graders perceive that now that they are in their last year of secondary study, they have to take on duties specific to their age and circumstance (e.g. exams preparation, graduation projects, standardized tests, social work, etc.) which affects their schedules.

"El nivel de tareas ha aumentado porque cuando estábamos más pequeñitos nos ponían como menos cosas y pues ahora que ya hemos ido creciendo, entonces, pues 
más responsabilidades, más madurez, más trabajos"

[Excerpt from interview, student \#15, eleventh grade]

Similarly, seventh graders affirm that they have more responsibilities than in primary school.

However, school requirements are not the primary factor which influences their schedule the most, but rather home duties and parental expectations. Some students explicitly indicated in the focus group that they have more responsibilities at home as reflected in the following excerpt:

“...pues como ya no nos colocan tanta tarea, por eso es que ahorita nos ponen a hacer aseo o a cocinar."

[Excerpt from focus group discussion, student \#1, seventh grade]

"Cuando mi mamá necesita algo ahí si ella dispone de mi tiempo"

[Excerpt from interview, student \#2, seventh grade]

Regarding parents' control over students, eleventh graders report to be more autonomous in their decision making while seventh graders, as mentioned above, carry out their daily activities are under parents' supervision. In this particular case, it is clear that the younger the students are, the fewer responsibilities they have at school and the more responsibilities they have at home. Accordingly, eleventh graders perceive a similar situation but claim that they are more autonomous in what they do.

As for leisure activities, seventh graders report to be involved in activities outside of their school and house duties. Nevertheless, these seventh graders are still largely led by their parents in terms use of free time, while eleventh graders choose how use their spare time by considering more their own likes and dislikes.

Student \#16 "no es que uno haga lo que quiera pero ya no lo molestan (los padres) a uno como antes"

[Excerpt from interview, student \#16, eleventh grade]

\section{Parental academic competence and help-seeking.}

With regard to help-seeking strategies, it was concluded in both groups that learners' perceptions of their parents' competence influences how they develop tasks. For instance, seventh graders consider that their parents are helpful when it comes to answering questions about homework when they are not related to English. Similarly, eleventh graders perceive that their parents are not competent in English; however, unlike the seventh graders, they find their parents less helpful in other scholastic domains. For example, parents of seventh graders can often help with basic English activities as well as with tasks for other subjects, whereas parents of eleventh graders 
are commonly considered less helpful across the board by their children. Most of the students in both groups reported that their parents do not have a professional academic education, and some of them did not finish primary or secondary school. The following excerpts illustrate this point:

"Pues a una tía que es egresada de la institución, a ella era a quien le pedía colaboración... (Me ayudó) hasta grado noveno... (le pido ayuda a) algunos compañeros"

[Excerpt f,rom focus group discussion, student \#16, eleventh grade]

"Porque los papás no saben"

[Excerpt from focus group discussion, all students, seventh grade]

"Mi papá hizo hasta segundo"

[Excerpt from focus group discussion, student \#4, seventh grade]

"Mi mamá no sabe escribir"

[Excerpt from focus group discussion, student \#10, seventh grade]

“... Le pido ayuda a mi hermano mayor... porque él entiende más el inglés

“...No a ellos no les pregunto (los padres)... porque no estudiaron"

[Excerpt from interview, student \#3, seventh grade]

Accordingly, the seventh graders showed a higher use of parental helpseeking strategies due to the fact that they see their parents as competent people who can support them. On the other hand, the eleventh graders primarily seek help via $3^{\text {rd }}$ party resources such as the internet.

Regarding this particular situation, it is important to highlight that both age-groups share socioeconomic features characterized by illiterate parents, low income, and familial dysfunction which could, in turn, be a determining factor in the development of students' strategic behavior. For instance, Castro, Giménez, and Pérez (2016) argue that among the identified factors that influence students' school performance, family dynamics have been noted in some studies to be more relevant than other factors such as institutional characteristics.

\section{Conclusions}

To recap, this study empirically revealed that age influenced the LLS use of seventh graders (aged 12-13) and eleventh (aged 16-17) graders. However, students within each age category might further be characterized in terms of setting, culture, and personality factors, all of which also impact LLS use. We can conclude that the use of strategies is closely related to grade level, across which task complexity increases as students advance and mature. This is similar to what Oxford (1989) has stated: "age is sometimes implied by course level" (p. 238). Another identified factor is the use of strategies resulting from the 
course delivery techniques of individual teachers as well as overall instructional methods for their grade, yielding a situation in which, as Prokops (cited in Chen, 2014, p. 149) found, students have to cope with different tasks particular to different methodologies and courses throughout their schooling as they grow up.

Furthermore, it is also important to consider students' inherent learning preferences since awareness of students' innate learning styles permits them to adapt learning strategies to suit different learning tasks in particular (Oxford as cited in Wong \& Nunan, 2011, p.146). For instance, curriculum designers and teachers should adapt the materials and methodologies taking into account the particular needs of the students and particular contexts (Tomlinson, 2001), such as the ones of the participants of this study.

It is our belief that by means of examining learners' LLS behavior, it is possible to improve practices in the classroom, keeping in mind the diversity and complexity of contexts throughout Colombian schools, which are particularly in need of intervention given the disregard of governmental policies which do not address areas in which English is not a priority (Cardenas, 2006), in part due to the challenging conditions in which institutions operate.

To accomplish the previous idea, both teachers and students should appreciate the value of raising self- awareness since "postponing learning strategy instruction until intermediate or advanced level courses deprives beginners of tools that could enhance language learning and increase motivation for further study" (Chamot, 2005, p.122).

We consider that the adaptations of different methods to identify LLS are relevant to the field since many of the available instruments were created for particular needs and the available ones for school students are complicated to handle and inaccessible for some teachers because they have to pay for them.

Although, it was evident that age is a determining factor in the LLS use, further research would be necessary to know to what extent consolidated sociocultural characteristics of the contexts could predispose some behaviors in relation to the development of LLS. Finally, the analysis presented in this study could be contrasted with longitudinal research in order to appreciate how LLS are simultaneously shaped throughout the years along the course levels as it was evidenced by the observed results of this research.

\section{References}

Ardasheva, Y., \& Tretter, T. (2013). Strategy Inventory for Language Learning-ELL Student Form: Testing for Factorial Validity. The Modern Language Journal, 97(2), 474-489. Retrieved from http:// www.jstor.org/stable/43651650 
Bialystok, E. (1981). The role of conscious strategies in second language proficiency. The Modern Language Journal 65.1 (1981): 24-35.

Brown, A. L. (1982). Learning, Remembering, and Understanding. Technical Report No. 244. 23.

Bruner, J. S., Goodnow, J. J., \& Austin, G. A. (1956). A study of thinking. NY: John Wiley \& Sons.

Burgess, R. G. (1984). In the field. London: Allen \& Unwin.

Cárdenas, M. (2006). Bilingual Colombia: are we ready for it? What is needed? Paper presented at the 19th Annual English Australia Education Conference Perth, Australia.

Castro, G., Giménez, G., \& Pérez, D. (2016). Educational Inequalities in Latin America, 2012 PISA: Causes of Differences in School Performance between Public and Private Schools (English version). Revista de Educacion, 376, 32-59.

Chamot, A. U. (2004). Issues in language learning strategy research and teaching. Electronic journal of foreign language teaching, 1(1), 14-26.

Chamot, A. U. (2005). Language learning strategy instruction: Current issues and research. Annual review of applied linguistics, 25, 112-130.

Chang, C. Y., Liu, S. C., \& Lee, Y. N. (2007). A study of language learning strategies used by college EFL learners in Taiwan. Mingdao Journal of General Education, 3, 235-261.

Chen, K. T., \& Jonas, A. M. (2009). Understanding Taiwanese College Students' Strategies for English Language.
Chen, M. L. (2014). Age differences in the use of language learning strategies. English Language Teaching, 7(2), 144. Chaoyang Journal of Humanities and Social Sciences, 7(1), 97-130.

Cohen, L., Manion, L., \& Marrison, K. (2007). Research in education. Sixth edition.

Creswell, J. W., \& Inquiry, Q. (2007). Research Design: Choosing among five approaches.

Derry, S. J., \& Murphy, D. A. (1986). Designing systems that train learning ability: From theory to practice. Review of Educational Research, 56(1), 1-39.

Duncan, T. G., \& McKeachie, W. J. (2005). The making of the motivated strategies for learning questionnaire. Educational Psychologist, 40(2), 117-128.

Droździał-Szelest, K. (1997). Language learning strategies in the process of acquiring a foreign language, Poznan, Motivex.

Ehrman, M., \& Oxford, R. (1990). Adult language learning styles and strategies in an intensive training setting. The modern language journal, 74(3), 311-327.

Ellis, R. (1989). Classroom learning styles and their effect on second language acquisition: A study of two learners. System, 17(2), 249262.

Fewell, N. (2010). Language learning strategies and English language proficiency: An investigation of Japanese EFL university students. TESOL Journal, 2(1), 159-174.

Fillmore. W. (1979). Individual differences in second language acquisition. Individual differences in Language Ability. Fillmore, C., Kempler, D. and Wang. W. (eds), New York: Academic Press.

Gardner, R. C., \& Lambert, W. E. (1959). Motivational variables in second-language 
acquisition. Canadian Journal of Experimental Psychology, 13, 266.

Gavriilidou, Z., \& Mitits, L. (2016). Adaptation of the Strategy Inventory for Language Learning (SILL) for students aged 12-15 into Greek: Developing an adaptation protocol. Selected papers on theoretical and applied linguistics, 21, 588-601.

Gómez, F., López, D., \& Marin, L. (2011). Reading comprehension in face-to-face and web-based modalities: graduate students' use of reading and language learning strategies in EFL. Colombian Applied Linguistics Journal, 13(2), 11-28.

Griffiths, C., \& Oxford, R. L. (2014). The twenty-first century landscape of language learning strategies: Introduction to this special issue. System, 43, 1-10.

Hood, M. (2009). Case study. In Heigham, J., \& Croker, R. (Eds.) Qualitative research in applied linguistics: A practical introduction. (pp. 81-82). Springer.

Krueger, R. A. (1988) Focus Groups: A Practical Guide for Applied Research. Beverly Hills, CA: Sage.

Kvale, S. (1996). Interviews. An introduction to qualitative research interviewing. Thousand Oaks, CA: Sage.

Lankshear, C., \& Knobel, M. (2004). A handbook for teacher research. McGrawHill Education (UK).

Lavasani, M. G., \& Faryadres, F. (2011). Language learning strategies and suggested model in adults processes of learning second language. Procedia-Social and Behavioral Sciences, 15, 191-197.

Lee, M. (2014). Development of an instrument of learning strategies for upper elementary school Students. PhD diss., University of
Tennessee, 2014.http://trace.tennessee. edu/utk graddiss/3147

Lee, K. R., \& Oxford, R. (2008). Understanding EFL learners' strategy use and strategy awareness. Asian EFL Journal, 10(1), 7-32.

Likert, R. (1932). A technique for the measurement of attitudes. Archives of psychology.

Marshall, C., \& Rossman, G. B. (1995). Data collection methods. Designing qualitative research, 2(8).

Morgan, D. L. (1988). Focus Groups as Qualitative Research. Beverly Hills, CA: Sage.

O'Malley, J. M., \& Chamot, A. U. (1990). Learning strategies in second language acquisition. Cambridge University Press.

Orrego, L \& Diaz, A. (2010). Empleo de estrategias de aprendizaje de lenguas extranjeras: inglés y francés», in Íkala, Revista de Lenguaje y Cultura, Vol. 15, $\mathrm{n}^{\circ} 24, \mathrm{p} .105-142$.

Oxford, R. L. (1989). Use of language learning strategies: A synthesis of studies with implications for strategy training. System, 17(2), 235-247.

Oxford, R. L. (1990). Language learning strategies: What every teacher should know. (Vol. 1, p. 990). New York: Newbury House.

Oxford, R. L. (1994). Language learning strategies: An update. Eric Diget. Washington D.C. ERIC Clearinghouse on Languages and Linguistics.

Oxford, R. L., \& Burry-Stock, J. A. (1995). Assessing the use of language learning strategies worldwide with the ESL/EFL version of the Strategy Inventory for 
Language Learning (SILL). System, 23(1), 1-23.

Oxford, R. L. (Ed.). (2003). Language learning styles and strategies. Mouton de Gruyter.

Pineda, J. E. (2010). Identifying language learning strategies: an exploratory study. GIST Education and Learning Research Journal, (4), 94-106.

Platsidou, M., \& Sipitanou, A. (2015). Exploring relationships with grade level, gender and language proficiency in the foreign language learning strategy use of children andearlyadolescents. International Journal of Research Studies in Language Learning, 4(1), 83-96.

Richards (2009). Interviews. In Heigham, J., \& Croker, R. (Eds.). Qualitative research in applied linguistics: A practical introduction. Springer.

Rubin, J. (1975). What the "good language learner" can teach us. TESOL quarterly,9(1), 41-51.

Russell, A. M. (2010). Assessment of strategy inventory of language learning (SILL) in students learning a second language.

Stern, H (1975). What can we learn from the good language learner? Canadian Modern Language Review, 34, 304-318

Stewart, D. W., Shamdasani, P. N., \& Rook, D. W. (1990). Focus groups: Theory and practice. Applied social research methods series. Focus groups: theory and practice applied social research methods series.

Stroud, K. C. (2006). Development of the school motivation and learning strategies inventory (Doctoral dissertation, Texas A\&M University).

Stroud, K. C., \& Reynolds, C. R. (2009). Assessment of learning strategies and related constructs in children and adolescents. The handbook of school psychology, 4 .

Tarone, E. (1981). Some Thoughts on the Notion of Communication Strategy. TESOL Quarterly, 15(3), 290. doi:10.2307/3586754

Tomlinson, B. (Ed.). (2011). Materials development in language teaching. Cambridge University Press.

Wade, S. E., Trathen, W., \& Schraw, G. (1990). An analysis of spontaneous study strategies. Reading Research Quarterly, 147-166.

Weinstein, C.E., \& Mayer, R.E. (1986). The teaching of learning strategies. In M.C. Wittrock (Ed.), Handbook of Research on Teaching, Third Edition (pp. 315327). New York: Macmillan. Goetz, \& P. A. Alexander (Eds.), Learning and study strategies: issues in assessment, instruction, and evaluation. (pp. 25-40). San Diego: Academic Press.

Weinstein, C. E., Schulte, A. C., \& Palmer, D. R. (2002). Learning and Study Strategies Inventory (LASSI). Clearwater, FL: H\&H Publishing Company.

Wilson, N., \& McClean, S. I. (1994). Questionnaire design: A practical introduction. Coleraine: University of Ulster.

Wong, L. L., \& Nunan, D. (2011). The learning styles and strategies of effective language learners. System, 39(2), 144163.

Zimmerman, B.J. \& Pons, M.M., (1990). Student differences in self-regulated learning: Relating grade, sex, and giftedness to self-efficacy and strategy use. Educational Psychology, 82, 51-59. 


\section{Appendixes}

Appendix 1

\section{PERCEPTIONS}

\begin{tabular}{|c|c|c|c|c|c|}
\hline \multirow{2}{*}{ Statement } & \multicolumn{4}{|c|}{ HOW FACTUAL THE STATEMENT IS. } \\
\cline { 2 - 6 } & $\begin{array}{c}\text { Never or } \\
\text { almost } \\
\text { never } \\
\text { true of } \\
\text { me. }\end{array}$ & $\begin{array}{c}\text { Usually } \\
\text { not true } \\
\text { of me. }\end{array}$ & $\begin{array}{c}\text { Somewhat } \\
\text { true of me. }\end{array}$ & $\begin{array}{c}\text { Usually } \\
\text { true of } \\
\text { me. }\end{array}$ & $\begin{array}{c}\text { Always or almost } \\
\text { always true of me. }\end{array}$ \\
$\begin{array}{c}\text { 1. I try to } \\
\text { memorize what } \\
\text { I've learned in } \\
\text { class. }\end{array}$ & 1 & 2 & 3 & 4 & 5 \\
\hline $\begin{array}{c}\text { 2. I look over } \\
\text { tables. }\end{array}$ & 1 & 2 & 3 & 4 & \\
\hline
\end{tabular}

\section{B. HOW DO I FACE MY OWN PERCEPTIONS}

\begin{tabular}{|c|c|c|c|c|c|}
\hline \multirow{2}{*}{ Statement } & \multicolumn{4}{|c|}{ HOW FACTUAL THE STATEMENT IS. } \\
\cline { 2 - 6 } & $\begin{array}{c}\text { Never or } \\
\text { almost } \\
\text { never } \\
\text { true of } \\
\text { me. }\end{array}$ & $\begin{array}{c}\text { Usually } \\
\text { not true } \\
\text { of me. }\end{array}$ & $\begin{array}{c}\text { Somewhat } \\
\text { true of me. }\end{array}$ & $\begin{array}{c}\text { Usually } \\
\text { true of } \\
\text { me. }\end{array}$ & $\begin{array}{c}\text { Always or almost } \\
\text { always true of me. }\end{array}$ \\
$\begin{array}{c}\text { 9. I listen well } \\
\text { when the teacher } \\
\text { is speaking. }\end{array}$ & 1 & 2 & 3 & 4 & 5 \\
\hline $\begin{array}{c}\text { 10. I check } \\
\text { answers before } \\
\text { turning in a test. }\end{array}$ & 1 & 2 & 3 & 4 & \\
\hline
\end{tabular}


C. MY PLANNING

\begin{tabular}{|c|c|c|c|c|c|}
\hline \multirow{2}{*}{ Statement } & \multicolumn{5}{|c|}{ HOW FACTUAL THE STATEMENT IS. } \\
\hline & $\begin{array}{l}\text { Never or } \\
\text { almost } \\
\text { never } \\
\text { true of } \\
\text { me. }\end{array}$ & $\begin{array}{c}\text { Usually } \\
\text { not true } \\
\text { of me. }\end{array}$ & $\begin{array}{l}\text { Somewhat } \\
\text { true of me. }\end{array}$ & $\begin{array}{l}\text { Usually } \\
\text { true of } \\
\text { me. }\end{array}$ & $\begin{array}{l}\text { Always or almost } \\
\text { always true of me. }\end{array}$ \\
\hline $\begin{array}{l}\text { 22. I make sure } \\
\text { my desk area is } \\
\text { neat. }\end{array}$ & 1 & 2 & 3 & 4 & 5 \\
\hline $\begin{array}{l}\text { 23. I have my } \\
\text { materials for } \\
\text { class ready. }\end{array}$ & 1 & 2 & 3 & 4 & 5 \\
\hline \multicolumn{6}{|c|}{ D. WHAT MAKES ME FEEL MOTIVATED } \\
\hline \multirow[b]{2}{*}{ Statement } & \multicolumn{5}{|c|}{ HOW FACTUAL THE STATEMENT IS. } \\
\hline & $\begin{array}{l}\text { Never or } \\
\text { almost } \\
\text { never } \\
\text { true of } \\
\text { me. }\end{array}$ & $\begin{array}{c}\text { Usually } \\
\text { not true } \\
\text { of me. }\end{array}$ & $\begin{array}{l}\text { Somewhat } \\
\text { true of me. }\end{array}$ & $\begin{array}{l}\text { Usually } \\
\text { true of } \\
\text { me. }\end{array}$ & $\begin{array}{l}\text { Always or almost } \\
\text { always true of me. }\end{array}$ \\
\hline $\begin{array}{l}\text { 30. I think things } \\
\text { I learn in class } \\
\text { are important. }\end{array}$ & 1 & 2 & 3 & 4 & 5 \\
\hline $\begin{array}{l}\text { 31. I have to be } \\
\text { better at school } \\
\text { work than my } \\
\text { friends. }\end{array}$ & 1 & 2 & 3 & 4 & 5 \\
\hline
\end{tabular}

